\title{
Emergency Preparedness: Knowledge and Perceptions of Latin American Immigrants
}

\author{
Olivia Carter-Pokras, $\mathrm{PhD}$ \\ Ruth E. Zambrana, PhD \\ Sonia E. Mora \\ Katherine A. Aaby, MPH, RN
}

\begin{abstract}
This paper describes the level of public emergency knowledge and perceptions of risks among Latin American immigrants, and their preferred and actual sources of emergency preparedness information (including warning signals). Five Latino community member focus groups, and one focus group of community health workers, were conducted in a suburban county of Washington D.C. $(\mathrm{N}=51)$. Participants came from 13 Latin American countries, and $64.7 \%$ immigrated during the previous five years. Participants had difficulty defining emergency and reported a wide range of perceived personal emergency risks: immigration problems; crime, personal insecurity, gangs; home/traffic accidents; home fires; environmental problems; and snipers. As in previous studies, few participants had received information on emergency preparedness, and most did not have an emergency plan. Findings regarding key messages and motivating factors can be used to develop clear, prioritized messages for communication regarding emergencies and emergency preparedness for Latin American immigrant communities in the U.S.
\end{abstract}

Key words: Hispanic Americans, culture, health education, disaster planning, civil defense, terrorism, qualitative research.

$\mathrm{T}$ here is an increasing recognition of the need to prepare the public for a wide range of hazards, from a terrorism incident to pandemic flu, natural disaster, or other emergency. ${ }^{1}$ Although extensive infrastructure for emergency preparedness has been developed since $2001,{ }^{2}$ sparse information is available on the knowledge, attitudes, and views among low-income Latin American immigrants in the United States (U.S.) of what constitutes an emergency and how to respond to one. Racial and ethnic minorities are more vulnerable to disasters than non-Hispanic Whites for many reasons including, but not limited to, socioeconomic differences, language barriers, minority preference for

OLIVIA CARTER-POKRAS is an Associate Professor in the Department of Epidemiology and Biostatistics at the University of Maryland College Park (UMCP). She can be reached at opokras@umd .edu. RUTH E. ZAMBRANA is a Professor in the Department of Women's Studies and Director of the Consortium on Race, Gender and Ethnicity at UMCP. SONIA MORA is Program Manager, Latino Health Initiative at the Department of Health and Human Services in Montgomery County, Maryland. KATHERINE AABY is Program Manager, Montgomery County Advanced Practice Center, Public Health Emergency Preparedness and Response Program at the Department of Health and Human Services in Montgomery County. 
particular information sources (e.g., family), and distrust of governmental authorities. ${ }^{3-9}$ A survey of New Yorkers one year after the attacks of September 11th found African Americans and Hispanics, those with less education or income, and those more likely to flee, are also more fearful than their counterparts of future terrorist attacks. ${ }^{10}$

Low-income Latinos are often at particular risk following a disaster since they lack access to financial and material resources to recover their losses and cushion the impact of the disaster. Studies of earthquakes in California suggest that poor Latinos, undocumented immigrants, and monolingual ethnic groups are among the groups that encounter the most problems in acquiring resources and recovering. ${ }^{11-12}$ Low-wage Latinos with fragile homes and livelihoods had limited access to post-disaster resources following Hurricane Andrew. ${ }^{13}$ This paper describes the level of public emergency knowledge and perceptions of risks among a group of Latin American immigrants, and their preferred and actual sources of emergency preparedness information (including warning signals).

Barriers to and facilitators of risk communication. Effective risk communication, or the "interactive process of exchange of information and opinion among individuals, groups and institutions"14 requires both knowledge of people from other cultures and respect for their diversity. ${ }^{15}$ Cultural groups respond to risk and crisis communication on the basis of their perceptions and ways of thinking, and these differ from group to group. ${ }^{16}$ Views are influenced by prior experiences, among other things. However, the lack of extensive research in the crisis and risk communication literature about differing cultural groups reveals is a weakness. ${ }^{17}$ Latinos, who represent the largest minority group in the U.S., with high rates of recent immigration from Central and South America and residential concentration in large, urban, segregated areas are a population at risk in the event of an emergency. The lack of information on this group's risk perception, combined with barriers relating to language, literacy, and access, place them at a unique disadvantage.

Language barriers are known to be an important contributor to the ineffectiveness of disaster information dissemination and related problems, particularly in multicultural communities. ${ }^{18-20}$ Disaster and hazard warnings in the U.S. are often broadcast only in English, leaving many ethnic minorities relatively susceptible to danger. ${ }^{21-22}$ In addition to language and literacy issues, unfamiliarity with organizational structures and requirements pose serious access barriers to available public and private resources for many U.S.-born and immigrant Latinos. For vulnerable, low-income Latino immigrants, material and personal loss can be exacerbated by more recent aggressive stances by federal and state governments against the provision of social services.

Community-based organizations and grassroots Latino community members trained as volunteer community health workers or health promoters have successfully provided public health messages to low-income Latino communities. Health promoters serve as connectors between communities and the health care system, providing informal counseling and social support, and ensuring that people obtain the services that they need. Using participatory educational methods and interventions, they help community members put new knowledge into practice. ${ }^{23}$ A growing body of literature establishes the unique role of health promoters. The use of health promoters in health intervention programs has been associated with improved health care access, prenatal care, preg- 
nancy and birth outcomes, client health status, health- and screening-related behaviors, appropriate diabetes care, and reduced health care costs. ${ }^{24-26}$ Although literature was not found on the role of Latino health promoters (promotores) in emergency preparedness, this exploratory study aimed to assess the knowledge level and perceptions of community members and promotores on emergency preparedness.

\section{Methods}

This qualitative study entailed focus groups to produce data and insights on perceptions on a defined area of interest through a planned discussion in a non-threatening environment; these data and insights might have never been attained without the interaction found in a group. ${ }^{27-28}$ Focus groups have been increasingly used in social science and health disparities research to obtain preliminary findings where limited information is available. ${ }^{29}$ Focus groups can be a useful tool in public health to assess needs, generate information, and develop plans and programs. ${ }^{30} \mathrm{~A}$ strength of focus groups is that community members become part of and contribute to solutions to community problems as participants. In the area of risk communication, focus groups have been used to gain access to various cultural and social groups, raise unexpected issues for exploration, and identify perceived risks and reactions to those risks. ${ }^{31-32}$

Description of Montgomery County Latino community. In Maryland, Latinos are the fastest growing racial/ethnic minority group, now representing 5.8\% of Maryland's and $13.7 \%$ of Montgomery County's population. ${ }^{33}$ Maryland's Latino population differs from that of the entire United States in that the vast majority are recent immigrants, many of whom are from Central America. Among counties nation-wide, Montgomery County Maryland ranks 16th in the nation for the proportion foreign-born. ${ }^{34}$

Development of discussion guide. In order to prepare for an expansion of an existing health promoter program to address emergency preparedness, Montgomery County Government (Advanced Practice Center for Public Health Emergency Preparedness and Response Program, and the Latino Health Initiative) and the University of Maryland collaborated to plan and conduct focus groups with low-income immigrant Latinos in Montgomery County, Maryland. All but one member of the research team were bilingual and bicultural.

The Latino Health Initiative's health promoter program is located in Montgomery County (a suburb of Washington D.C.). Established in 2000, Montgomery County Government's Latino Health Initiative (LHI) uses a multifaceted approach to develop new culturally and linguistically specific strategies and model programs, expand and improve health services and programs, improve data collection, and develop partnerships with organizations that focus on Latino health. The Montgomery County Public Health Emergency Preparedness and Response Program is one of eight Advance Practice Centers funded by the Centers for Disease Control and Prevention (CDC) and the National Association of County and City Health Officials (NACCHO) to develop cutting-edge tools and resources for local public health agencies nationwide to prepare for, respond to, and recover from major emergencies.

Guided by previous experience from the Latino Health Initiative's health promoter program and a review of the literature, the Montgomery County Government-University 
of Maryland research team collaboratively developed a sociodemographic questionnaire and guides for the moderator and note-taker. The purpose of the discussion guide was to elicit information on level of public emergency knowledge, perceptions of risks, and preferred and actual sources of information (including warning signals) among recently migrated Latinos residing in Montgomery County. Participants were asked questions to define an emergency, provide a list of emergencies, and identify signals they recognized as signs of emergencies and the sources of information that they were most likely to rely on in an emergency. To benefit from prior health education experiences of the health promoters, a few additional questions were asked of the participants in the health promoter focus group (one group) but not of the community members (five groups). These additional questions covered whether definitions of an emergency were thought to differ between the health promoters and the broader Latino community, key messages to motivate the community to take immediate action in the event of an emergency and who the messages should be directed to, the best format to educate the community about preparing for an emergency, and suggestions for supporting material for related talks in the community.

Five focus groups with Latino community members and one focus group with lay health promoters (promotores) were conducted between May and August 2006. Recruitment aims were 10 participants per group, for a total of 60 individuals. Latino adult participants at least 18 years of age were identified by LHI staff, health promoters, and the staff of three community-based agencies and clinics serving the target population (Camino de La Vida United Methodist church, Community Ministries of Rockville, and Court Appointed Special Advocates for Children (CASA) of Maryland). Fortyfive community members participated in five focus groups held at Camino de La Vida United Methodist church in Gaithersburg, Twinbrook Baptist Church in Rockville, and CASA of Maryland in Wheaton. To solicit information from health promoters with similar background characteristics to those who would be trained in emergency preparedness for the program, one focus group was conducted with six health promoters at the Latino Health Initiative office in Silver Spring Maryland. Since the purpose of the project was to plan an expansion of an existing health promoter program to include emergency preparedness, the number of focus groups was limited by the timeframe and amount of resources available for the assessment phase. Each participant received a \$30 supermarket food certificate and a meal as an incentive for his or her participation. Childcare was provided to encourage participation. Prior approval was requested and obtained from the University of Maryland Institutional Review Board (IRB) and participants signed written consent forms in advance of their participation. The written consent forms in Spanish outlined the purpose of the focus groups: to help develop culturally appropriate materials and programs to meet the emergency preparedness needs of the community.

A Colombian bilingual (English/Spanish) facilitator, experienced in planning and conducting focus groups in Spanish, facilitated the focus groups and performed the initial content analysis of the data. All focus groups were facilitated in Spanish. Each session was tape-recorded to allow for analysis and the preparation of reports of the findings from the discussion. Audiotapes were destroyed following analysis per IRB-approved 
protocol. A note taker, fluent in Spanish, was trained to unobtrusively observe and take written notes using a note-taker's guide to recording participants' comments, as well as group dynamics and non-verbal communication (expressions, gestures, movements) that emphasized or supported points being made.

Notes and audiotapes were reviewed for each focus group and common themes mentioned across each focus group were identified using manual review in the original language. Audiotapes were transcribed and translated into English. Two bilingual/ bicultural investigators reviewed the data and independently verified the themes. For purposes of accuracy, and to capture the cultural meaning of the response, we provide the original Spanish used by participants for key terms and concepts that are not easily translated into English. While data from each of the focus groups were analyzed separately, no significant differences emerged among the six groups with respect to thematic content or background. The findings are therefore presented as a summary of all groups.

\section{Results}

A total of 51 individuals participated in 6 focus groups: 30 women and 15 men in 5 focus groups of community members, and 6 women in a focus group of promotoras. Community participants came from 13 Latin American countries, including the Dominican Republic (1), Mexico (4), Central America [El Salvador (14), Guatemala (4), Honduras (1), Nicaragua (1), Panama (1)], and South America [Bolivia (5), Chile (1), Colombia (3), Ecuador (4), Peru (10), Venezuela (1)]. As shown in Table 1, 64.7\% of participants had immigrated during the previous 5 years. Approximately half (52.9\%) of the participants were employed, with an additional $17.6 \%$ working independently. Forty-three percent of participants had not completed high school in their country of origin or the U.S.

Perceptions of an emergency situation. One set of questions concerned perceptions of an emergency situation, definition of an emergency, and perceived emergencies in the United States. When the groups were asked, "When you think of an emergency situation, what situation(s) come to mind?" participants mentioned a wide variety of situations. These included natural disasters (earthquakes/tremors, hurricanes, snowstorms) as well as in-home fires, gangs (maras), terrorism, traffic accidents, and illnesses (e.g., heart attacks, flu). In four of the six groups, the majority of participants related emergency situations and stories that were common in their countries of origin or other parts of the U.S. where they had lived (e.g., earthquakes, hurricanes), although few had lived through one of these situations.

Participants had difficulty defining emergency, most often describing situations that put people at risk. One individual described an emergency as:

Anything that is happening that you don't have control over and that puts you in danger [Cualquier cosa que este pasando que uno no tiene control y lo pone en peligro]

Another participant suggested the following definition: 
Table 1.

SOCIODEMOGRAPHIC CHARACTERISTICS OF PARTICIPANTS

\begin{tabular}{|c|c|c|}
\hline Characteristic & $\%$ & (n) \\
\hline \multicolumn{3}{|l|}{ Gender } \\
\hline Male & 29.4 & (15) \\
\hline Female & 70.6 & (36) \\
\hline \multicolumn{3}{|l|}{ Country of origin } \\
\hline Dominican Republic & 2.0 & (1) \\
\hline Mexico & 7.8 & $(4)$ \\
\hline Central America & 41.2 & (21) \\
\hline South America & 47.1 & (24) \\
\hline N/A & 2.0 & $(1)$ \\
\hline \multicolumn{3}{|l|}{ Age range (years) } \\
\hline 18 to 25 & 15.7 & $(8)$ \\
\hline 26 to 35 & 19.6 & $(10)$ \\
\hline 36 to 45 & 33.3 & (17) \\
\hline 46 to 55 & 19.6 & (10) \\
\hline 56 to 65 & 11.8 & (6) \\
\hline \multicolumn{3}{|l|}{ Marital status } \\
\hline Never married & 27.5 & (14) \\
\hline Married or living with partner & 54.9 & (28) \\
\hline $\begin{array}{l}\text { Separated or divorced } \\
\text { Employment }\end{array}$ & 17.6 & (9) \\
\hline Employed & 52.9 & (27) \\
\hline Working independently & 17.6 & (9) \\
\hline Unemployed or unable to work & 13.7 & (7) \\
\hline Housemate or student & 15.7 & (8) \\
\hline \multicolumn{3}{|l|}{ Salary/week } \\
\hline Less than $\$ 350$ & 43.1 & (22) \\
\hline More than $\$ 350$ & 33.3 & (17) \\
\hline Don't know or N/A & 23.5 & (12) \\
\hline \multicolumn{3}{|l|}{ Formal schooling } \\
\hline Less than high school & 43.2 & (22) \\
\hline High school graduate & 41.2 & (21) \\
\hline Technical school & 7.8 & $(4)$ \\
\hline Student & 2.0 & (1) \\
\hline N/A & 5.9 & (3) \\
\hline \multicolumn{3}{|l|}{ Years in U.S. } \\
\hline Less than 1 & 19.6 & (10) \\
\hline $1-3$ & 13.7 & (7) \\
\hline $3-5$ & 31.4 & (16) \\
\hline $6-10$ & 19.6 & (10) \\
\hline More than 10 & 7.8 & $(4)$ \\
\hline $\mathrm{N} / \mathrm{A}$ & 7.8 & (4) \\
\hline
\end{tabular}


A silent monster that when it attacks you don't know it [Un monstruo silencioso... cuando te ataca no lo sabes]

Other terms used for emergency included: alert, red alert, precaution, panic, chaos, and confusion.

When participants were asked about emergency situations they believed we were at highest risk of encountering in the United States, and in the area, participants in four groups mentioned terrorism, making comments such as the following:

I know that bioterrorism is a problem, but I don't know very much about it [Se que bioterrorism es un problema, pero no se mucho de eso]

The terrorism that happened in New York and here in Washington [El terrorismo que paso en Nueva York y aqui en Washington]

Yes ... I see a lot on TV ... the terrorist danger [Sí . . veo mucho en la TV sobre el peligro de los terroristas]

Other emergency situations that participants believed that we are at highest risk for in the U.S. included: bioterrorism (e.g., anthrax), avian virus (virus de los pajaros, epidemia de pollo), in-home fires and accidents (at work, in the car, personal), war, social risks such as gangs, natural disasters (e.g., no water), and the heat. Two focus groups were held in the late afternoon of a 100-degree day in rooms where the air conditioning systems were not working properly. Hence, many of the comments by the participants were framed around and referred to ambient heat as an emergency.

Participants, without exception, mentioned current immigration issues and the uncertain environment in this respect as representing an emergency situation and creating a sense of personal risk:

I think that the problem of our legal status is a big emergency [Creo que el problema de nuestro estatus legal es una emergencia muy grande]

We are frightened because we don't know what 's going to happen (with immigration) ... this is an emergency [Estamos asustados porque no sabemos lo que va a pasar (con imigracion)]

Some people don't even want to go out (of their house) [Hay gente que no quiere salir (de su casa)]

Crime, personal insecurity, gangs ("That gang thing has gotten uncontrollable and it's a real problem for all of us" [Eso de las maras esta incontrollable y es un problema para todos]); home/traffic accidents; home fires, environmental problems ("Pollution is a problem ... in the air and water" [La contaminacion es un problema en el agua $y$ el aire]) and snipers ("The sniper situation a few years ago created a real problem and emergency") were viewed as emergency risks for the area where they lived. The health promoters viewed emergency risks similarly:

Yes, the people perceive emergency situations the same, but the difference is that the community is less informed ... there's no help from the people above ... the 
government [Si la gente percibe las situaciones de emergencia igual, pero la diferencia es que no estan bien informados... no hay ayuda de la gente arriba del gobierno]

The problem is that they don't know how to express what they feel . . they keep quiet. [El problema es que no saben expresar lo que sienten ... se quedan callados]

What constitutes an emergency signal and response plan. Emergency signals that participants recognized and reported included alarms (smoke detectors, alarms at work); phone calls from family members or friends; police, ambulance or fire engine sirens; television and radio announcements; people running ("If people are running ... each person is on their own" [Si hay gente corriendo ... salvase el que pueda]); and church bells.

The vast majority of participants had not received information on emergency preparation.

We are not prepared, people don't think that it can happen from one moment to the other [No estamos preparados, la gente no piensa en que puede pasar de un momento a otro]

Information is lacking ... we don’t know anything. [Hace falta información ... no sabemos nada]

Only four participants had an emergency plan, and those were incomplete ('I've told my kids that if something ever happened, we should meet in a central location ... We haven't decided where"). Approximately half of parents with school-age children (about $80 \%$ of participants) had heard about an emergency plan in their children's schools from their children, but the vast majority was unable to describe it specifically:

I know that they are supposed to stay in the school if something happens, but I really don't know what else to do.

The information is not shared with the parents . . . the kids know, but they [the schools] don't tell us anything.

When asked why people don't have a plan, much of the discussion revolved around the lack of information or the fact that people were too busy working to make those types of plans. A general theme is that people wait until something happens to act ("The community reacts when it has already happened" [La comunidad reacciona una vez les pasa]). Some felt that there was no way to prepare for an emergency [No hay forma de preparer] and used this popular Hispanic saying: “. . . during an emergency there is no Saint Lucia that is worth anything" [ . . durante una emergencia no hay Santa Lucia que valga].

There was some confusion regarding the questions: "What steps would you take if you heard an emergency warning? What would be the first thing that you would do? Why?" and "How would you prepare to respond to an emergency situation? How would you prepare your family?" When specific examples of emergencies (snowstorm or terrorist attack) were provided by the facilitators, participants mentioned basic 
subsistence items, such as food, water, and blankets, as well as working channels of communication ("The first thing that I would do is make sure my cell phone and TV cable are working"), being calm and trusting God ("In a disaster everyone runs ... they are not prepared because they haven't lived it before . . you have to be calm and trust God"), and getting and disseminating information ("Investigate what type of an emergency it is and let the neighbors know").

Motivation to plan for an emergency and sources of information. Factors that would motivate the participants to prepare for an emergency and seek information included: to stay alive, for my family, to be informed so we could help others, and feeling secure with knowledge. The notion that it is difficult to get the community to think ahead of time about emergencies and planning was also expressed:

Latinos are lazy to read informational bulletins and go to meetings ... sometimes the school holds the meetings to talk about things like this, but very few of us show up ... and they wait until it happens to react. [Los latinos tienen pereza de leer boletines informativos ... ir a reuniones... a veces las escuelas hacen reuniones pero pocos estamos ahí... esperan que les pase para reaccionar]

Promotoras agreed that the focus of any educational effort on emergency preparedness in the community should be directed at all of the family, and stressed that it is important that the information provided be consistent.

As shown in Box 1, reported sources that are trusted to provide information on emergencies included firemen and police; the Red Cross; charismatic individuals who are well trained; doctors; community leaders; television and radio announcers; and Spanish-language newspapers. (It should perhaps be noted, however, that one participant remarked, "No one reads now a days ... it's easiest to get information on TV or radio [when you're working].") The groups were unanimous in saying that whoever the person was, he or she should be well informed, should be Latino, and should speak Spanish. Participants noted that "Univisión and Telemundo don't transmit signs of alert" [ . . no transmiten señales de alerta], and that local cable television shows may not be accessible. The forms in which participants wanted to receive information included courses or seminars; television or radio programs; pamphlets, flyers, or manuals; and through simulations or practice ("We need to unite the theory with the practice").

There was general agreement that governmental entities are trusted sources of information ("If it's not the government ... who else?" [Si no es el gobierno . . quien mas?]), but a few participants expressed concern about how ready the government is to deal with an emergency ("We saw what happened in New Orleans . . . it's all the same"). Roles that participants said the government could play include: providing courses and training in churches, schools and work; making economic resources available; having doctors and hospitals ready; alerting the community; and orienting the community to what to do during different types of emergencies. Promotoras also saw a role that they could play by providing talks (charlas) in the community, but they emphasized that they must be well trained on how to educate the community for emergencies and how to prepare, and also that they need good support materials (such as manuals, videos, and handouts to distribute to the community). 


\section{Box 1. \\ SOURCES OF INFORMATION AND \\ PREFERENCES FOR RECEIPT OF \\ EMERGENCY PREPAREDNESS INFORMATION}

Reported most trusted sources of information (in rank order)

1. Firemen and police

2. Red Cross

3. Some one who is well trained with charisma

4. Doctors

5. Community leaders

6. TV and radio

7. Spanish-language newspapers

Reported preferences for receiving information (in rank order)

1. Courses or seminars

2. TV or radio programs

3. Pamphlets, flyers or manuals

4. Participating in simulations or practice

Perceptions of role government can play in preparing Latino community

(in rank order)

1. Provide courses and training (e.g., churches, schools, work)

2. Make economic resources available

3. Have the doctors and hospitals ready

4. Alert the community

5. Orient the community on what to do

Reported messages to communicate to the Latino community

- Be calm (calma)

- Be alert (esten atentos)

- Be united (esten unidos)

- Act (actuar)

- Keep important telephone numbers handy and prepare

Messages that participants said could be used to communicate with the Latino community included: be calm (calma, calma, calma), be alert (estén atentos), be united (estén unidos), and act (actuar), as well as messages reminding people to keep important telephone numbers handy and to prepare. Promotoras added the following messages: "Do you know how to distinguish emergencies?" [Sabes distinguir una emergencia?], "Let's reduce the risk ... prepare yourself for an emergency" [Reduzcamos el riesgo ... prepárate para una emergencia]. Materials that the promotoras suggested could be used when giving a talk in the community included pencils, bags with slogans on the side, flashlights, Band-aids, and other small gifts. 


\section{Discussion}

This exploratory study reveals a consistent theme among the participants of a significant need to increase the Latino community's knowledge and preparedness with regard to emergencies, including among community-based health promoters who serve as critical connectors to resources and information. Consistent with recent general population surveys, ${ }^{35-36}$ few focus group participants had received information on emergency preparedness, and most did not have emergency plans. The mention of terrorism, anthrax, and avian virus as emergency situations that might arise in the U.S., suggests that participants are aware of current issues for which the federal government has invested resources to raise awareness. (For example, the federal government website, www.ready.gov, now has Spanish language materials and public service announcements.) In addition, the Washington D.C. area has directly experienced both anthrax and terrorism emergency situations. ${ }^{37-38}$

However, the matter of relative risk in comparison with other priority issues faced by the community should be considered. Additionally, although the focus of our research was on recent Latino immigrants residing in Montgomery County Maryland, the Latino community in the Washington D.C. metropolitan area is diverse in terms of birthplace/generation, national origin, English language ability, social class, race, and previous experience with natural disasters. These differences may matter a great deal for communication during emergencies. Prior experiences with emergencies influence one's response to a new one. In studies of responses to the Los Angeles earthquake, Bolin found that Mexican immigrants who experienced the Mexico city earthquake responded very differently from those without experience, and undocumented residents responded very differently from how U.S. citizens responded. ${ }^{11-12}$

A key new finding from our focus groups is that the topic of current immigration issues was clearly and significantly identified as an emergency by the participants and was perceived as a risk for the Latino community. Increased anti-immigrant sentiment and efforts to restrict immigrant access to driver's licenses, educational opportunities, health care, and other services have had ripple effects throughout the Latino community. ${ }^{39-41}$

Participants noted the need to identify a credible spokesperson to deliver a consistent and unified message around emergencies and preparedness. They consistently identified first responders (e.g., police, firefighters, ambulance, Red Cross) as trusted sources of information. There is increasing recognition of the need to have this cadre of workers fully trained (among other things, by including an adequate number of culturally competent, fluent Spanish-speakers in their ranks) to respond to the needs of the Latino community. ${ }^{42}$

Establishing interconnected networks of public health workers and other first response organizations is an important goal of emergency preparedness. Emergency personnel also must be informed of the fears of immigrants who do not have legal residence in the U.S., since the perception of immigration concerns as an emergency has important implications not only for emergency preparedness, but also for response, relief, and recovery. One study reported that, following Hurricane Katrina, undocumented immigrants avoided recovery assistance for fear of deportation, and some eligible Latinos 
who were legal residents did not receive correct information from Federal Emergency Management Agency (FEMA) regarding housing assistance due to confusion regarding eligibility. ${ }^{9}$ In their testimony to Congress following Hurricane Katrina, Oxfam America and the Mississippi Immigrants Rights Alliance noted the importance of building trust prior to a disaster, maintaining that trust in the delivery of emergency services, knowing the communities, and developing plans from that knowledge. ${ }^{43}$ The National Council of La Raza recommends that both public and private sectors do what is necessary to ensure that trained professional relief workers, volunteers from diverse communities, and managers are pre-positioned for the next disaster deployment. ${ }^{9}$ In addition to receiving Latino-focused training, first responders should have an active and continuing role in the development and delivery of educational and informational messages to the community. These messages can be included in Spanish-language announcements on television and radio programs that low-income Latinos hear.

Limitations of these findings include their restriction to one geographic area, selfselection of the group of respondents (that may lead us to over-estimate or underestimate the true level of emergency preparedness in the broader Latino community), and an inability to assess how participants would respond in an actual emergency. However, these data confirm the lack of emergency preparedness in a segment of the Latino population and suggest that additional inquiry by documenting the level of emergency preparedness among other Latino groups is warranted.

Implications and conclusions. The study results are being used to guide the design and development of specific emergency preparedness education concepts and messages (including terminology), and strategies to be incorporated into a culturally and linguistically appropriate training curriculum for health promoters. The information is also being used to guide the development of material(s) to support the health promoters' outreach and education efforts. Prior experience with promotores has demonstrated that simple, low-literacy materials focusing on a limited number of key messages are an effective means of delivering information to the target population by promotores.

Although not specifically mentioned as a credible source of information on public emergencies by community member participants, promotores have served as effective vehicles for health education in Montgomery County on other topics. Furthermore, a Florida study found that Latino homeowners are more likely than non-Latino homeowners to prefer to use friends and family as sources of disaster preparation information. ${ }^{44}$ Latinos are also more likely than non-Latino Whites to use social networks and neighborhood meetings as communication channels for disaster and hazard information. ${ }^{6,8,45}$ Grass-roots mobilization interventions by promotores and others can therefore complement television and radio to deliver messages. Once fully trained, promotores can conduct educational sessions at community-based organizations, churches, place of employment, and other sites. Promotores can organize community response teams to conduct simulations of emergencies, to review appropriate/inappropriate responses, and to emphasize practical steps for preparedness.

There is currently a pool of over 100 trained volunteer Latino health promoters providing effective education and outreach to the Latino population of Montgomery County in a wide range of areas (e.g., access to care, cancer screening services, 
pedestrian safety, HIV prevention and testing, tobacco-use prevention). These health promoters represent an important resource that can be developed to contribute to the overall, long-term goal of Montgomery County's public health emergency preparedness program. These data demonstrate the need to increase knowledge among Latinos of public health emergency threats and appropriate responses to them, knowledge of planning and preparing for public health emergencies (e.g., emergency preparedness kits, shelter-in-place [small interior room, with few or no windows to take refuge]). Thus, community-based participatory approaches can be effectively executed to develop culturally and linguistically appropriate emergency preparedness educational interventions, and to strengthen the existing infrastructure.

Developers of clear, prioritized messages regarding emergencies and emergency preparedness for the Latino community should recognize that prior experiences with emergencies in countries of origin may affect emergency preparation and responses of Latino immigrants. Infrastructure development for emergencies is in its preliminary stages in many communities throughout the U.S. Thus, augmenting the capacity of health response workers is imperative and in the Latino community it would be wise to capitalize on the cadre of Spanish-speaking Latino professional relief workers, health promoters, and managers who are committed and ready to develop the knowledge and skills in emergency preparedness.

\section{Acknowledgments}

This research was supported by Cooperative Agreement Number U50/CCU302718 from the Centers for Disease Control and Prevention (CDC) to the National Association of County and City Health Officials (NACCHO). Its contents are solely the responsibility of the authors and do not necessarily represent the views of the CDC or the NACCHO.

\section{Appendix A-Questions Used to Guide Focus Group Discussion}

\section{Perceptions}

a. When you think about an emergency situation, what situation(s) comes to mind?

b. How would you define the word emergency? What other name or term would you use for an emergency?

c. In your country of origin, are emergency situations known by another name/term? Which?

d. What are the emergency situations that you believe we are at highest risk for in this country [the US]? How about in the area where you live? Why?

e. Of these situations which one(s) do you consider yourself personally at risk for?

For Promoters:

a. Do you believe that the Latino community sees (perceives) emergency situations the same way you do? Why? Why not? 


\section{Knowledge}

a. How would you know that you are in an emergency situation?

b. Are you aware of any alert system that warns us that we are in danger of an emergency? Which one? What does it say?

c. Are you aware of any specific plans for emergencies in your children's school? What does it consist of?

d. Have any of you ever received information on how to prepare for an emergency? [If someone has, ask the following:] From where/whom? What did it say? What action did you take as a consequence of having received the information?

\section{Preparation}

a. Which steps would you take if you heard an emergency warning? What would be the first thing that you would do? Why?

b. How would prepare to respond to an emergency situation? How would you prepare your family?

c. Do you have a specific plan in case of an emergency? What does it consist of? [If they don't, ask:] Why not?

d. What would motivate you to prepare for an emergency and seek information on what to do during an emergency?

e. What do you think Latinos can do to become better informed about preparing for an emergency?

For Promoters:

a. Which message or messages would use to motivate the community to take immediate action in case of an emergency? To whom should the message be directed? (parents, children, family) Why?

\section{Trusted Sources and Information}

a. Whom would you trust to talk to you about emergencies?

b. What source of information do you think are the most credible? Why?

c. How or in what form would you prefer to learn more about preparing for and handling an emergency? Why?

d. What do you think should be the role of governmental organizations in helping prepare for and handling an emergency? Would you trust governmental organizations?

e. If we wanted to share with the Latino community information on preparing for an emergency, what would the information consist of? What would be the best way to communicate the information?

f. What messages would you communicate to the community about preparing for an emergency?

For Promoters:

a. Based on your experience, which is the best form to teach to the community about preparing for an emergency? What would be the most effective message(s) to teach the community what to do in case of an emergency? 
b. If you were to give a talk (charla) in the community, and were to use materials to support you, what materials do you believe would be most effective in the community? What characteristics would the materials have that you would consider most effective?

Is there anything else you would like to share?

\section{Notes}

1. United States Government Accountability Office. Hurricane Katrina: GAO's preliminary observations regarding preparedness, response, and recovery. Statement of David M. Walker, Comptroller General of the United States. Testimony before the Senate Homeland Security and Governmental Affairs Committee. (GAO-06-442T.) Washington, DC: Government Accountability Office, 2006. Available at http://www .gao.gov/new.items/d06442t.pdf.

2. Geberding JL. Protecting health—the new research imperative. JAMA. 2005 Sep 21; 294(11):1403-6.

3. Kasperson RE, Golding D, Tuler S. Social distrust as a factor in sitting hazardous facilities and communication risks. J Soc Issues. 1992;48:161-87.

4. Perry HS, Lindell MK. The effects of ethnicity on decision-making. Int J Mass Emerg Disasters. 1991;9(1):47-68.

5. Phillips BD. Cultural diversity in disasters: sheltering, housing, and long term recovery. Int J Mass Emerg Disasters. 1993;11(1):99-100.

6. Perry RW, Mushkatel AH. Minority citizens in disaster. Athens, GA: University of Georgia Press, 1986.

7. Vaughn E. The significance of socioeconomics and ethnic diversity for the risk communication process. Risk Anal. 1995;15(2):169-80.

8. Phillips BD, Ephraim M. Living in the aftermath: blaming process in the Loma Prieta earthquake. (Working Paper no. 80.) Boulder, CO: University of Colorado, IBS, Natural Hazards Research and Applications Information Center, 1992.

9. Muniz B. In the eye of the storm: how the government and private response to Hurricane Katrina failed Latinos. Washington, DC: National Council of La Raza, 2006. Available at http://www.nclr.org/content/publications/download/36812.

10. Boscarino JA, Figley CR, Adams RE. Fear of terrorism in New York after the September 11 terrorist attacks: implications for emergency mental health and preparedness. Int J Emerg Mental Health. 2003 Fall;5(4):199-209.

11. Bolin R, Stanford L. The Northridge earthquake: community-based approaches to unmet recovery needs. Disasters. 1998 Mar;22(1):21-38.

12. Bolin R. The Northridge earthquake: vulnerability and disaster. New York: Routledge, 1998.

13. Morrow BH, Peacock WG. Disasters and social change: Hurricane Andrew and the reshaping of Miami? In: Peacock WG, Morrow BH, Gladwin H, eds. Hurricane Andrew: ethnicity, gender and the sociology of disasters. New York: Routledge, 1997; 226-42.

14. Committee on Risk Perception and Communication, National Research Council. Improving risk communication. Washington, DC: National Academies Press, 1989.

15. Samovar LA, Porter RE, McDaniel ER. Communication between cultures. Wadsworth Publishing, 2006. 
16. Lindell MK, Perry RW. Communicating environmental risk in multiethnic communities. Thousand Oaks, CA: Sage, 2004.

17. Seeger MW. Best practices of risk and crisis communication: an expert panel process. J Appl Commun Res. 2006 Aug;34(3):232-44.

18. Fothergill A, Maestas EG, Darlington JD. Race, ethnicity and disasters in the United States: a review of the literature. Disasters. 1999 Jun;23(2):156-73.

19. Peacock WG, Girard C. Ethnic and racial inequalities in hurricane damage and insurance settlements. In: Peacock WG, Morrow BH, Gladwin H, eds. Hurricane Andrew: ethnicity, gender and the sociology of disasters. New York: Routledge, 2000.

20. Perry RW, Nelson L. Ethnicity and hazard information dissemination. Environ Manage. 1991 Jul;15(4):581-7.

21. Aguirre BE. The lack of warnings before Saragosa tornado. Int J Mass Emerg Disasters. 1988 Mar;6(1):65-74.

22. Lindell MK, Perry RW, Greene MR. Race and disaster warning response. Seattle, WA: Battelle Human Affairs Research Centers, 1980.

23. Wiggins N, Barbon A. Core roles and competencies of community health advisors. In: Rosenthal EL, Wiggins N, Brownstein JN, et al. Final report of the National Community Health Advisory Study: weaving the future. Tucson, AZ: University of Arizona Press, 1998.

24. Community Health Worker and Promotora de Salud Workgroup, CDC Division of Diabetes Translation. Community health workers/promotores de salud: critical connection in communities. Atlanta, GA: Centers for Disease Control and Prevention, 2003.

25. Earp JA, Eng E, O’Malley MS, et al. Increasing use of mammography among older, rural African American women: results from a community trial. Am J Public Health. 2002 Apr;92(4):646-54.

26. Rosenbach M, Ellwood M, Czajka J, et al. Implementation of the State Children's Health Insurance Program: synthesis of state evaluations. Background for the report to Congress. Cambridge, MA: Mathematica Policy Research Inc., 2003;123-7.

27. Morgan DL. Focus groups in qualitative research. Newbury Park, CA: Sage, 1988; 12.

28. Krueger RA. Focus groups: a practical guide for applied research. Newbury Park, CA: Sage, $1988 ; 18$.

29. Ruff CC, Alexander IM, McKie C. The use of focus group methodology in health disparities research. Nurs Outlook. 2005 May-Jun;53(3):134-40.

30. Marshall C, Rossman GB, Designing qualitative research, $3 \mathrm{~d}$ ed. Thousand Oaks, CA: Sage Publications, 1999;115.

31. Blanchard JC, Haywood Y, Stein BD, et al. In their own words: lessons learned from those exposed to anthrax. Am J Public Health. 2005 Mar;95(3):489-95.

32. McGough M, Frank LL, Tipton S, et al. Communicating the risks of bioterrorism and other emergencies in a diverse society: a case study of special populations in North Dakota. Biosecur Bioterror. 2005;3(3):235-45.

33. U.S. Census Bureau. 2005 American Community Survey. Selected social characteristics. Washington, DC: U.S. Census Bureau, 2006.

34. U.S. Census Bureau. Table 2: County ranking - percent of population that is foreign born. Washington, DC: U.S. Census Bureau, 2003 Sep. Available at http://www .census.gov/Press-Release/www/2003/ACSTables.html.

35. National Center for Disaster Preparedness. Where the American public stands on 
terrorism, security and disaster preparedness: five-years after September 11, oneyear after Hurricane Katrina. New York: Columbia University, 2006 Sep. Available at http://www.ncdp.mailman.columbia.edu/files/2006_white_paper.pdf.

36. JKV Research, LLC. Washington County Community Health \& Emergency Preparedness Survey. Fond du Lac, WI: Quad Counties Public Health Consortium, 2006. Available at http://www.co.washington.wi.us/washington/Pubs/WashingtonCounty BTSurveyReport.pdf.

37. Centers for Disease Control and Prevention (CDC). Update: Investigation of bioterrorism-related anthrax and interim guidelines for exposure management and antimicrobial therapy, October 2001. MMWR. 2001 Oct 26;50(42):909-19.

38. National Commission on Terrorist Attacks Upon the United States. The 9/11 Commission report: final report of the National Commission on Terrorist Attacks Upon the United States. Washington, DC: Government Printing Office, 2004.

39. Donato KM, Massey DS, Wagner B. The chilling effect: public service usage by Mexican migrants to the United States. Presented at: Annual Meeting of the Population Association of America, Los Angeles (CA), Jan 2006. Available at http://paa2006 .princeton.edu/download.aspx?submissionId $=61871$.

40. Pupovac J. Local immigration measures raise a host of new concerns. The New Standard. 2006 Oct 24. Available at http://newstandardnews.net/content/index.cfm/ tems/3808.

41. Anti-defamation League (ADL). The Ku Klux Klan today. Washington, DC: ADL, 2007. Available at http://www.adl.org/learn/ext_us/kkk/klan_report.pdf.

42. Dell'Orto G. First responders learning Spanish. Associated Press. 2006 Nov 27. Available at https://www.mmrs.fema.gov/news/publichealth/2006/nov/nph2006-11-29b .aspx.

43. Chandler B, Gamboa G. Hurricane Katrina response and immigrants. Written testimony for the record to the Select Bipartisan Committee to Investigate the Preparation for and Response to Hurricane Katrina. Boston, MA: Oxfam America, 2006 Dec 6. Available at http://www.oxfamamerica.org/newsandpublications/publications/ research_reports/research_paper.2005-12-06.4237647120.

44. Peguero AA. Latino disaster vulnerability: the dissemination of hurricane mitigation information among Florida's homeowners. Hisp J Behav Sci. 2006;28(1):5-22.

45. Blanchard-Boehm D. Risk communication in southern California: ethnic and gender response to 1995 revised, upgraded earthquake probabilities. Research report. Boulder, CO: University of Colorado, Natural Hazards Research Center, 1997. 